\title{
Results from black tiger shrimp Penaeus monodon culture ponds stocked with postlarvae PCR-positive or -negative for white-spot syndrome virus (WSSV)
}

\author{
Boonsirm Withyachumnarnkul*
}

Department of Anatomy, Faculty of Science, Mahidol University, Rama VI Road, Bangkok 10400, Thailand

\begin{abstract}
Commercial, intensive, earthen shrimp ponds (188) in southern Thailand were stocked with postlarvae (PL) of Penaeus monodon that had tested positive or negative for white-spot syndrome virus (WSSV) infection by polymerase chain reaction (PCR) assay. All the PL were grossly healthy. At 2 wk intervals after stocking, shrimp from each pond were examined for gross WSSV lesions and tested for WSSV by PCR. Shrimp from all the ponds stocked with WSSV-PCR-positive PL (Group 0, n = 43) eventually showed gross signs of white-spot disease (WSD) at an average of $40 \mathrm{~d}$ after stocking. Of the remaining ponds stocked with WSSV-PCR-negative PL $(n=145)$, some remained WSSV-PCR-negative throughout the study (Group 5, $\mathrm{n}=52$ ), while others (93) became WSSV-PCR-positive after stocking, during the first month (Group 1, $\mathrm{n}=23$ ), second month (Group 2, $\mathrm{n}=40$ ), third month (Group 3, n = 24), or fourth month (Group $4, \mathrm{n}=6$ ). Crop failure was defined as a pond drain or forced harvest before 14 wk or $98 \mathrm{~d}$ of cultivation. For Group 0 the proportion of ponds failing was 0.953 , while it was only 0.019 for Group 5. Thus, the relative risk of failure for Group 0 was approximately 50 times that of Group 5. The relative risk of failure for Group 0 was also 3 times that for ponds stocked with WSSVPCR-negative PL. Obviously, not all WSSV outbreaks resulted in crop failure. Of the 93 ponds stocked with PCR-negative PL that later yielded WSSV-PCR-positive shrimp, $53 \%$ reached successful harvest. The study showed that PCR screening of PL and rejection of WSSV-positive batches before stocking could greatly improve the chances of a successful harvest
\end{abstract}

KEY WORDS: Penaeus monodon - Black tiger shrimp - Culture - White-spot disease Polymerase chain reaction. White-spot syndrome virus . WSSV

\section{INTRODUCTION}

For Asian cultivation of the giant tiger shrimp Penaeus monodon, white-spot syndrome virus (WSSV) still causes the most devastating disease losses (for review, see Flegel et al. 1997). These losses have been estimated at millions of US dollars for Thailand and other countries (Rosenberry 1995). In Thailand, WSSV is also called systemic ectodermal and mesodermal baculovirus (SEMBV) (Chou et al. 1995, Wang et al. 1995, Wongteerasupaya et al. 1995, 1996). Sensitive techniques using a polymerase chain reaction (PCR) have been developed (Lo et al. 1996a, Wongwisansri 1996) to assist farmers in screening $P$. monodon postlarvae (PL) for WSSV before stocking of ponds, and

•E-mail: pimfern@asianet.co.th this practise has been carried out for several years in Thailand. Although the rationale seems correct, there has been some doubt as to whether stocking of WSSVPCR-positive fry would really lead to white-spot disease outbreaks. This report comprises a retrospective analysis of data recorded from one large commercial shrimp farm in southern Thailand where WSSV-PCRpositive and -negative PL were used to stock rearing ponds. The purpose of the analysis was to determine the relative risk of crop failure resulting from the use of PCR-positive PL to stock ponds.

\section{MATERIALS AND METHODS}

A commercial intensive shrimp farm in southern Thailand was stocked with Penaeus monodon fry during June to October 1996. The farm comprised 188 
earth-ponds of variable size, ranging from 0.5 to 1.0 hectare, that have been used for $P$. monodon culture for more than $3 \mathrm{yr}$. This farm adopted the method of 'semi-closed' cultivation, by which water exchange was minimized to reduce the chance of introducing water-borne carriers of yellow head virus (YHV) and WSSV (Lan et al. 1996, Lo et al. 1996b). When necessary, water exchange was carried out from a pretreated reservoir, which was considered relatively free of these viruses and their carriers. This farm, however, did not use crab exclusion fences around the ponds during the interval covered by the study, although several types of crabs are known to be WSSV carriers (Lan et al. 1996, Lo et al. 1996b) and although the practise of using such fences is now common in Thailand.

For stocking, PL13-PL15 were purchased from commercial sources. Individual batches of fry were screened for the presence of WSSV using a single-step PCR according to Wongwisansri (1996). About 50 PL were randomly sampled from individual nursery tanks and pooled as 1 sample for the PCR procedure. The fry were fixed in $95 \%$ ethanol, homogenized with $0.5 \mathrm{ml}$ lobster haemolymph buffer (LHB), boiled at $100^{\circ} \mathrm{C}$ for $10 \mathrm{~min}$ and then centrifuged at $7000 \mathrm{rpm}(5000 \times \mathrm{g})$ for $5 \mathrm{~min}$ at room temperature. Next, $5 \mu \mathrm{l}$ of the supernate was removed and added to $50 \mu \mathrm{l}$ of PCR reaction mixture (PCR buffer pH 9.0, $1.5 \mathrm{mM} \mathrm{MgCl}_{2}, 1 \mathrm{mM}$ of each deoxynucleotide triphosphate, $1 \mu \mathrm{M}$ of each primer and $2 \mathrm{U}$ of Taq DNA polymerase). The mixture was overlaid with $50 \mu \mathrm{l}$ of mineral oil to prevent evaporation and the PCR reaction was then carried out for 35 cycles of denaturation, annealing and polymerization (1 cycle of heat denaturation at $90^{\circ} \mathrm{C}$ for $3 \mathrm{~min}$, annealing at $60^{\circ} \mathrm{C}$ for $30 \mathrm{~s}$ and polymerization at $72^{\circ} \mathrm{C}$ for $30 \mathrm{~s}$ followed by 34 cycles of denaturation at $90^{\circ} \mathrm{C}$ for $30 \mathrm{~s}$, annealing at $60^{\circ} \mathrm{C}$ for $30 \mathrm{~s}$ and polymerization at $72^{\circ} \mathrm{C}$ for 30 s except for the final cycle with extension at $72^{\circ} \mathrm{C}$ for $5 \mathrm{~min}$ ). The primers yielded a 294 base pair fragment specific for WSSV DNA (Wongteerasupaya et al. 1996, Kanchanaphum et al. 1998) and the amplified product was detected by electrophoresis of $20 \mu \mathrm{l}$ aliquots through $1.5 \%$ agarose gel.

PL stocking was performed during June to October 1996, but not all the 188 ponds were stocked at the same time. During June and the first half of July, all the fry stocked were WSSV-negative. It was during the second half of July that the first batch of WSSV-positive fry were introduced. From that time on, both positive and negative fry were randomly stocked until late October. Whether WSSV-PCR-positive or -negative, all batches of PL used for stocking were grossly normal in appearance and behavior and also gave no evidence of WSSV infection by normal histological analysis. The stocking density was 50 to 60 pieces $\mathrm{m}^{-2}$.
During culture, 2 to 5 shrimp from individual ponds were randomly sampled for WSSV-PCR at $2 \mathrm{wk}$ intervals. Most of the samples were from the center of the pond, where sediment had accumulated. Gill and subcuticular epithelium of individual shrimp (approximately $100 \mathrm{mg}$ fresh weight) were combined, homogenized with $0.5 \mathrm{ml}$ LHB and processed through the PCR amplification as described for the PL. The pond was considered to be a WSSV-infected pond whenever any of the samples were detected as WSSV-PCR-positive. The ponds were grouped according to time of first obtaining WSSV-PCR-positive results. Ponds in Group 0 were stocked with WSSV-PCR-positive PL. Those in Groups 1 to 4 were stocked with WSSV-PCR-negative PL but yielded WSSV-PCR-positive specimens during Months 1 to 4, respectively. Ponds in Group 5 were stocked with WSSV-PCR-negative PL and yielded samples that were WSSV-PCR-negative throughout the study period. Following WSSV-PCR-positive results, shrimp health conditions were closely observed. The shrimp were considered to show gross signs of WSSV infection whenever they showed the following combination of gross signs: decreased feed intake, swimming at the water surface near the dike, inactivity, white spots in the exoskeleton of the carapace and/or the last abdominal segment, sometimes red body coloration on the body, and mass mortality over the period of a few days (Flegel et al. 1997). Diagnosis was confirmed by rapid histological examination (Flegel et al. 1997) and WSSV-PCR. Whenever mass mortality began, the culture was terminated and the culture period was counted from the stocking day to the day of termination. For purposes of the study, a crop failure in which WSSV was diagnosed by gross signs and histopathology was designated as a cultivation period of less than 14 wk or $98 \mathrm{~d}$, since periods of at least $98 \mathrm{~d}$ are usually required to obtain shrimp of a sufficient size for a profitable harvest. Thus, some ponds with WSSV outbreaks were successful, when the period of cultivation was $98 \mathrm{~d}$ or more and marketable shrimp were harvested.

All the values are expressed as means \pm standard errors. Since the data collected failed normality tests, statistical comparisons were performed for pairs as Mann-Whitney rank sum tests and for groups as 1-way analysis of variance on ranks followed (where appropriate) by multiple pairwise comparisons by the Student-Neuman-Keuls method using SigmaStat computer software (Jandel Scientific).

\section{RESULTS}

In Group 0 ponds $(n=43)$ (stocked with WSSV-PCRpositive PL), 40 of 43 ponds were terminated within the first 3 mo of cultivation. The remaining 3 ponds were 

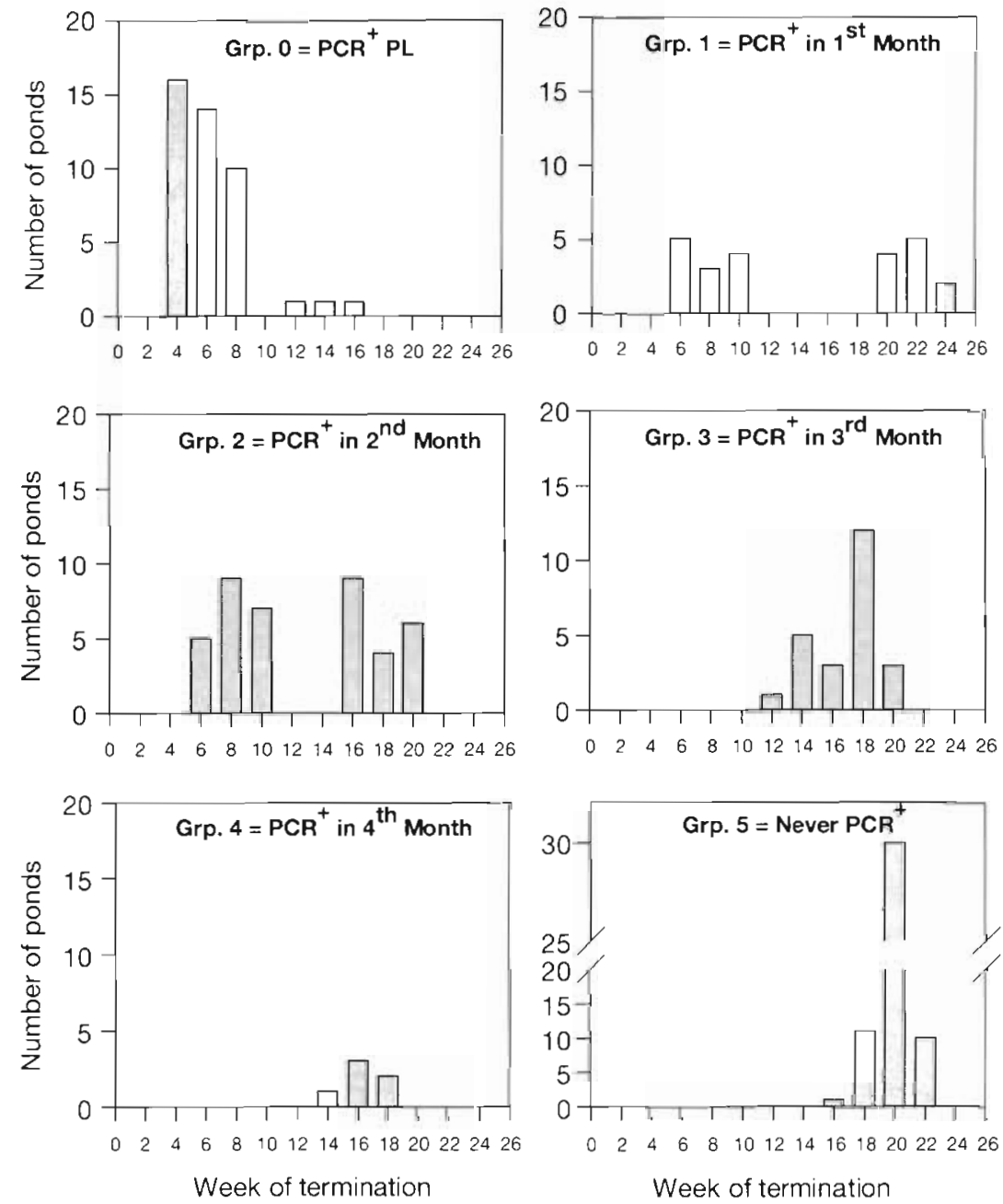

Fig. 1. Comparison of shrimp pond Groups 0 to 5 with respect to time of crop termination after stocking. Periods of termination were divided into 2 wk intervals from the time of stocking. The distribution of termination times was clearly bimodal for Groups 1 and 2

cultured for 77,98 and $105 \mathrm{~d}$. Thus, the proportion of ponds failing was $95 \%(41 / 43)$. The average culture period was $40 \pm 3$ d (i.e. about $6 \mathrm{wk}$ ).

In Group 1 ponds ( $\mathrm{n}=23$ ), stocked with WSSV-PCRnegative $\mathrm{PL}$ but yielding positive samples during the first month after stocking, 12 were terminated within the second month and 11 gave successful harvests, with culture periods extending up to more than $120 \mathrm{~d}$. Thus, the proportion failing in Group 1 was $52 \%(12 / 23)$. The average culture period in these ponds was bimodal with means at $7.3 \pm 1.4$ and $20.9 \pm 1.5 \mathrm{wk}$ (Fig. 1). Taken together, the overall proportion failing in Groups 0 and 1 was $80 \%$ (53/66).

In Group 2 ponds ( $\mathrm{n}=40), 19$ failed while 21 reached successful harvest. Thus, the proportion failing was approximately $48 \%$. This was similar to the results for Group 1. The average culture period in Group 2 was also bimodal with means at $7.5 \pm 1.4$ and $17.0 \pm 1.8 \mathrm{wk}$ (Fig. 1) and with the maximum and minimum cultivation times being 130 and $33 \mathrm{~d}$.

The bimodal distribution of short and long cultivation times for Groups 1 and 2 (Fig. 1) was curious. Their mean times for early termination $(7.3$ and $7.5 \mathrm{wk}$ ) were not significantly different $(p>0.05)$ although they did differ significantly from the mean termination time for Group 0 (5.8 wk) $(\mathrm{p}<0.05)$. Their mean times for late termination (20.9 and $17.0 \mathrm{wk}$ ) did not differ significantly from each other or from the mean termination times of Groups 3, 4 and 5 (16.5 \pm 2.1 , $15.7 \pm 1.5$ and $19.5 \pm 1.3$, respectively). This feature also appeared when the data for all of the WSSV-PCR-positive ponds (i.e. Groups 0 to 4) were pooled (Fig. 2). When the pooled data was arbitrarily divided into 2 groups for early loss ( 76 ponds, Weeks 4 to 12 ) and late loss (60 ponds, Weeks 14 to 24 ), the mean termination times
Fig. 2. Summary of data from pond Groups 0 to 4 compared to those from pond Group 5. All ponds in Groups 0 to 4 gave a PCR-positive result at some time during cultivation (i.e. including those stocked WSSV-PCR-positive PL). The summary data are also bimodal
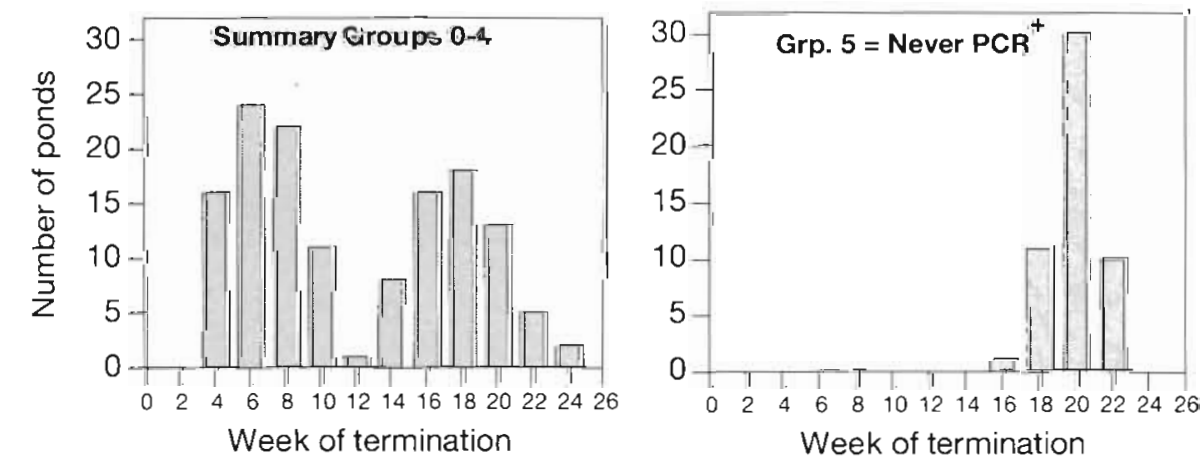
were $6.5 \pm 2.2$ and $17.4 \pm 2.5 \mathrm{wk}$, respectively, and these were significantly different by the Mann-Whitney rank sum test $(p<0.05)$. In these combined groups, the majority of the short cultivation ponds were terminated within 8 wk after stocking, while most of the long cultivation ponds were terminated at $16 \mathrm{wk}$ or more. Thus, there was an interval of more than 1 mo after the first $60 \mathrm{~d}$ of cultivation when WSSV-PCR-positive ponds were rarely terminated. It could be inferred that WSSV-PCR-positive ponds were likely to be successful if they could pass through the first 2 mo of cultivation without occurrence of a WSSV outbreak.

In Group 3 ponds $(\mathrm{n}=24), 15$ were successfully harvested and 9 failed. Thus, the proportion failing was approximately $48 \%$, similar to the proportion in Groups 1 and 2 . The average culture period was $106 \pm$ $3 \mathrm{~d}$ (Fig. 1). In Group 4 ponds $(\mathrm{n}=6), 4$ failed and 2 reached successful harvest. The average culture period for the group was $106 \pm 4$ d (Fig. 1).

All batches of PL used were visually normal, whether they tested WSSV-PCR-positive or -negative. The results from cultivation of these PL are summarized in Table 1, together with calculations for probability of crop failure and relative risk of failure when compared to Group 5, the group that was WSSV-PCR-negative throughout the study. The relative risk of crop failure (Table 1) in Group 0 ponds was approximately 50 times $(0.95$ vs 0.019$)$ that for Group 5 ponds. The risk of failure for Group 0 was also 3 times that for Groups 1 to 5 combined (Table 2). In addition, it can be seen in Fig. 3 that the percentage of ponds remaining in cultivation over time was much higher for combined Groups 1 to 5 than it was for Group 0. Also, the relative risk of failure for combined Groups 0 to 4 was approximately 33 times that for Group 5 (Table 3).

Once a WSSV-PCR-positive result was obtained for samples from a pond, a white-spot disease outbreak followed in all cases, although the length of time to the
Table 1. Relative risk of failure (compared to Group 5) and proportion of failure in 6 pond groups defined according to WSSV-PCR status of samples before and after stocking. na $=$ not applicable

\begin{tabular}{|lcrcc|}
\hline Pond group & $\begin{array}{c}\text { No. of } \\
\text { ponds }\end{array}$ & $\begin{array}{c}\text { No. } \\
\text { failed }\end{array}$ & $\begin{array}{c}\text { Proportion } \\
\text { failed }\end{array}$ & $\begin{array}{c}\text { Relative } \\
\text { failure risk }\end{array}$ \\
\hline $0\left(\mathrm{PCR}^{+} \mathrm{PL}\right)$ & 43 & 41 & 0.953 & 49.6 \\
$1(1 \mathrm{st}$ mo PCR & & & & \\
$\left.2(2 \mathrm{nd} \mathrm{mo} \mathrm{PCR})^{+}\right)$ & 40 & 19 & 0.522 & 27.1 \\
$3(3 \mathrm{rd} \mathrm{mo} \mathrm{PCR})$ & 24 & 9 & 0.475 & 24.7 \\
$4\left(4\right.$ th mo $\left.\mathrm{PCR}^{+}\right)$ & 6 & 4 & 0.375 & 19.5 \\
$5\left(\right.$ never $\left.\mathrm{PCR}^{+}\right)$ & 52 & 1 & 0.019 & 34.7 \\
Total & 188 & 86 & 0.457 & na \\
\hline
\end{tabular}

Table 2. Comparative risk of failure and proportion of failure in ponds stocked with WSSV-PCR-positive (Group 0) and -negative (Groups 1 to 5) PL batches. na = not applicable

\begin{tabular}{|lrrcc|}
\hline Pond group & $\begin{array}{r}\text { No. of } \\
\text { ponds }\end{array}$ & $\begin{array}{c}\text { No. } \\
\text { failed }\end{array}$ & $\begin{array}{c}\text { Proportion } \\
\text { failed }\end{array}$ & $\begin{array}{c}\text { Relative } \\
\text { failure risk }\end{array}$ \\
\hline $\begin{array}{l}\text { (PCR } \\
\text { PL })\end{array}$ & 43 & 41 & 0.953 & 3.1 \\
$1-5$ & 145 & 45 & 0.310 & na \\
Total & 188 & 86 & 0.457 & na \\
\hline
\end{tabular}

Table 3. Comparative risk of failure and proportion of failure in ponds tested WSSV-PCR-positive (Groups 0 to 4) at any time compared to the pond never positive for WSSV (Group 5) na $=$ not applicable

\begin{tabular}{|lrrcc|}
\hline Pond group & $\begin{array}{r}\text { No. of } \\
\text { ponds }\end{array}$ & $\begin{array}{c}\text { No. } \\
\text { failed }\end{array}$ & $\begin{array}{c}\text { Proportion } \\
\text { failed }\end{array}$ & $\begin{array}{c}\text { Relative } \\
\text { failure risk }\end{array}$ \\
\hline $\begin{array}{c}0-4 \text { (PCR }^{+} \\
\text {at some time) }\end{array}$ & 136 & 85 & 0.625 & 32.9 \\
$\begin{array}{l}\left.\text { (never } \mathrm{PCR}^{+}\right) \\
\text {Total }\end{array}$ & 52 & 1 & 0.019 & na \\
\hline
\end{tabular}

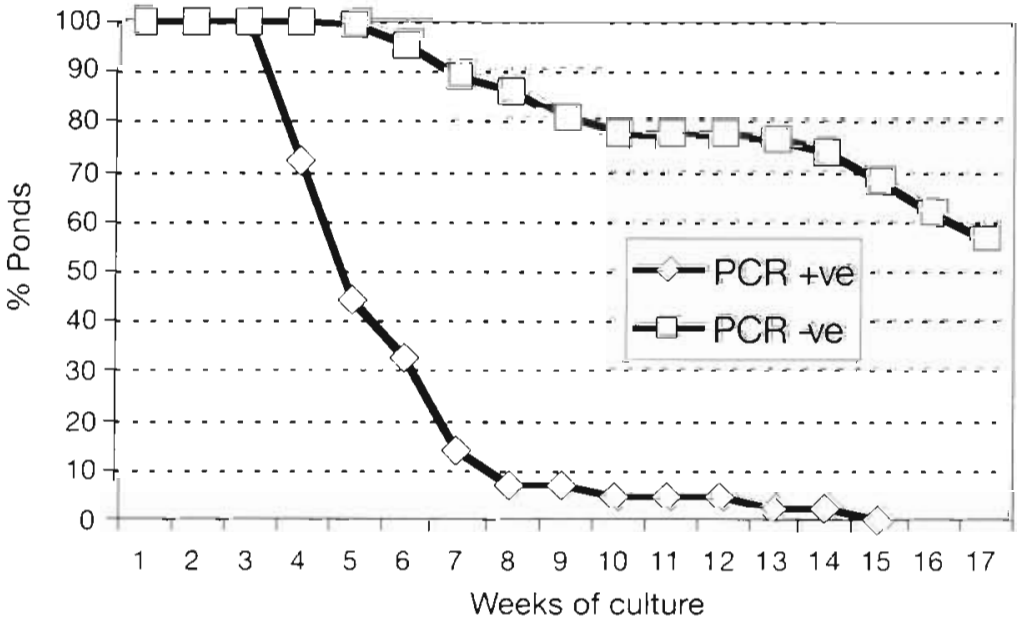

outbreak varied greatly and although late outbreak ponds gave successful harvests. For Group 0 ponds $(n=43)$ the mean time to termination was $39 \pm 3 \mathrm{~d}$ (minimum $30 \mathrm{~d}$ and maximum $105 \mathrm{~d}$ ). For pond Groups 1 to $5(n=145)$ the mean and maximum times to termination were similar at $45 \pm 4$ and $96 \mathrm{~d}$, respectively. However, there was a

Fig. 3. Percentage of ponds remaining in cultivation over time for Group 0 ponds (i.e. 43 ponds stocked with PL positive for WSSV by PCR) and for combined Groups 1 to 5 (i.e. 145 ponds stocked with PL negative for WSSV by PCR) 
marked contrast for the minimum, which was only $4 \mathrm{~d}$ The period of the outbreaks was from September to December 1996.

White-spot disease outbreaks first occurred in ponds stocked with PCR-positive PL and then in nearby ponds. No outbreaks occurred during June and July, the period during which all the stocked fry were PCRnegative. During the interval September 16 to 30, the first WSSV outbreaks occurred in 4 ponds within the first month after stocking. Five more ponds stocked with WSSV-PCR-negative PL yielded positive samples in this period and had subsequent WSSV outbreaks. Three of the 5 were situated adjacent to ponds stocked with WSSV-PCR-positive fry, although 2 were further away. The outbreaks then gradually occurred in other areas, all over the farm. Most outbreaks occurred either in ponds situated near diseased ponds or in ponds stocked with WSSV-PCR-positive fry.

Most ponds stocked with WSSV-PCR-positive fry continuously yielded WSSV-PCR-positive samples $(80 \%)$ but some $(20 \%)$ yielded WSSV-PCR-negative samples in the first month after stocking, only to give WSSV-PCR-positive samples in the following month. The negative results could easily have arisen from sampling since the number of shrimp taken at each interval was very small. In any case, all surviving ponds stocked with WSSV-PCR-positive fry gave positive samples continuously after the second month. Of the 145 ponds that were stocked with negative fry but gave WSSV-positive samples during subsequent cultivation, most ( $40 / 93$ or $43 \%$ ) became WSSV-PCR-positive during the second month after stocking, compared to only about $25 \%$ in each of the first and third months.

\section{DISCUSSION}

This study has clearly shown the advantage of WSSV-PCR screening of PL before stocking of cultivation ponds in that the risk of crop failure from WSSVPCR-positive PL was 3 times that from WSSV-PCRnegative PL. The ponds stocked with grossly normal but PCR-positive PL (i.e. larvae with latent WSSV infections) developed into WSSV outbreak ponds in approximately $40 \mathrm{~d}$. It was also found that the time to outbreak after first positive WSSV-PCR detection in ponds stocked with WSSV-PCR-negative PL was approximately $45 \mathrm{~d}$. These data suggest that the incubation period for WSSV in ponds is 40 to $45 \mathrm{~d}$ (if the initial viral challenge is low) and that outbreaks during the first 40 to $45 \mathrm{~d}$ of cultivation probably occur via stocked PL and not via horizontal transmission. It also suggests that WSSV is not rapidly transferred horizontally in shrimp ponds and that the precipitous mortality seen in WSSV outbreaks is either the culmination of an exponential spread or the result of an environmental trigger, both of which could have important implications for pond management strategy.

Although the average period from WSSV-PCR detection to outbreaks was 40 to $45 \mathrm{~d}$, the incubation period in experimental infections of WSSV is 4 to $7 \mathrm{~d}$ (Pratanpipat et al. 1996) and viral replication can be detected by PCR as early as $6 \mathrm{~h}$ after injection into shrimp (Kanchanaphum et al. 1998). The longer apparent incubation period in natural infections than in experimental infections could be related to viral dose and route of infection, since experimental shrimp are usually injected or bathed with high doses of viral extracts.

Of the ponds from Group $1(n=23)$ and Group 2 ( $n=$ 40 ), originally stocked with PCR-negative PL, the termination dates fell into 2 categories: those terminated within approximately $70 \mathrm{~d}$ or $10 \mathrm{wk}$ after stocking ( $\mathrm{n}=$ 33 ) and those terminated beyond $98 \mathrm{~d}$ or $14 \mathrm{wk}$ after stocking ( $\mathrm{n}=30$ ) (Fig. 1). It is possible that the ponds terminated early were stocked with WSSV-infected PL that failed to be detected by the WSSV-PCR assay procedure (i.e. false-negative PL batches). If this is so, then the false-negative WSSV-PCR test proportion would have been $33 / 145$ (23\%). By this argument, the remaining 30 ponds from Groups 1 and 2 and 30 ponds from Groups 3 and 4 (total $=60 / 145$ ) should have become WSSV-positive via horizontal transfer $(41 \%)$. On the other hand, most pond operators do not exchange water for the first $30 \mathrm{~d}$ of culture, and this should drastically reduce the risk of horizontal transfer until the second month. Adding this $30 \mathrm{~d}$ to the estimated incubation time of $40 \mathrm{~d}$ (total $=70 \mathrm{~d}$ ), we might expect that horizontal transfer ponds would be terminated at the earliest in the third month of cultivation (i.e. at some time beyond $70 \mathrm{~d}$ ). By this argument, the WSSV-PCR-positive ponds shown for Groups 1 and 2 in Fig. 1 (total 63 ponds) would mostly have resulted from false-negative PL, while those for Groups 3 and 4 (total 30 ponds) would mostly have resulted from horizontal transfer. This would increase the proportion of false-negative WSSV-PCR tests from 23 to $43 \%$ $(63 / 145)$ and decrease the proportion of horizontal transfer ponds from 41 to $21 \%$. If this second explanation is correct, we are left to explain the unusual bimodal distribution of Group 1 and 2 ponds shown in Figs. 1 \& 2. Obviously, the issues regarding false-negative PL batches are in urgent need of further study.

By the arguments in the previous paragraph, the proportion of ponds to which WSSV may have been horizontally transferred via neighbouring infected ponds or by unknown carriers ranged from 21 to $41 \%$. Although this may be a rather high proportion of all ponds stocked with WSSV-PCR-negative PL, the number of failures in these ponds was very low $(n=4)$. In 
Table 4. Estimated relative risk of failure (compared to Group 5) from presumed horizontal transfer and false-negative WSSV-PCR results upon screening of PL. na $=$ not applicable

\begin{tabular}{|c|c|c|c|c|}
\hline & $\begin{array}{l}\text { No. of } \\
\text { ponds }\end{array}$ & $\begin{array}{c}\text { No. } \\
\text { failed }\end{array}$ & $\begin{array}{l}\text { Proportion } \\
\text { failed }\end{array}$ & $\begin{array}{c}\text { Relative } \\
\text { failure risk }\end{array}$ \\
\hline \multicolumn{5}{|c|}{ False-negative WSSV-PCR test } \\
\hline Low estimate & 33 & 33 & 1.000 & 52.6 \\
\hline High estimate & 63 & 33 & 0.524 & 27.6 \\
\hline \multicolumn{5}{|c|}{ Presumed horizontal transfer } \\
\hline Low estimate & 30 & 3 & 0.100 & 5.3 \\
\hline High estimate & 60 & 3 & 0.050 & 2.6 \\
\hline Groups $1-5$ & 145 & 45 & 0.310 & 3.1 \\
\hline Group 5 & 52 & 1 & 0.019 & na \\
\hline
\end{tabular}

other words, the relative risk of crop failure from horizontal transfer may be low when compared to that from false-negative WSSV-PCR tests (Table 4).

The pattern of disease spread suggested that the virus could be transferred amongst ponds by waterborne vectors (Lan et al. 1996), water seepage, or poor sanitary practises (e.g. use of shared nets, boats or other equipment). Spread by crabs moving among ponds was also possible (Lan et al. 1996, Kanchanaphum et al. 1998, Supamataya et al. 1998), since the ponds in this farm were not equipped with crab protection fences.

False-negative results during PL screening could have occurred due either to low sensitivity of the PCR technique used or to sampling error. The sensitivity of the WSSV-PCR detection method was high at approximately 50 virus particles per PCR assay tube containing a $5 \mu$ aliquot of supernatant from the PL homogenate (Wonwisansri 1996, Kanchanaphum et al. 1998), and this compares favorably with other methods reported in the literature (Lo et al. 1996a,b). On the other hand, the possibility of a sampling error was high. The PL used during this study came from nursery stocks containing at least 500000 PL. A sample of 50 from 100000 or more is sufficient only to detect disease prevalence above 5\% with 95\% confidence (OIE 1997), so that PL batches with lower prevalence would have had a high probability of yeilding false-negative results. The error could be reduced by increasing the sampling frequency or the sample number. We currently recommend that samples of $150 \mathrm{PL}$ be homogenized $195 \%$ confidence of detecting $2 \%$ prevalence; OIE 1997). However, the procedure is still vulnerable to false-negative results when the number or severity of infections in the sampled population is very low. PCR assay sensitivity may be increased by using the nested PCR technique (Lo et al. 1996a,b). It is possible that a sufficiently low presence of WSSV in a PL population could be tolerated and not lead to a pond out- break within the commercial cultivation period. This interesting hypothesis, however, cannot be assessed by the present data. However, Lo et al. (1998) have shown that non-nested WSSV-PCR-positive PL and shrimp quickly develop patent WSSV infections, while those positive by only nested WSSV-PCR can survive for long periods without overt signs of disease if reared under optimum conditions.

Other possible explanations for the bimodal pattern of WSSV occurrence in pond Groups 1 and 2 involve arguements regarding (1) different pond conditions favorable or unfavorable to outbreaks, (2) different genetic response of various PL batches to WSSV, and (3) different adaptive responses of various PL batches to a small amount of virus in their population.

There is no direct evidence to either support or deny the first possibility. All the ponds that succeeded were in close proximity to infected ponds that failed, and the environment, water quality and management practises were not obviously different. Data to support the second possibility are not available either, although some PL batches from the same hatchery performed differently. The effect of PL genetics cannot be answered without access to identified PL batches from a welldocumented breeding program. The last possibility, that shrimp have the capability to respond to viral infections by adaptive defense, requires more supportive evidence. Some have proposed that the possibility exists (Adams 1991, Sung et al. 1991), while others deny it (Söderhäll \& Cerenius 1992). Flegel \& Pasharawipas (1998) have theorized that shrimp are capable of adaptive accommodation of viral pathogens by exposure to viral epitopes during early larval stages and that the process can lead to survival in the presence of an otherwise lethal pathogen. On the basis of their theory, the bimodal distribution of ponds in Groups 1 and 2 could be explained to result from 2 types of ponds, those stocked with accommodative PL (cultivation period over $98 \mathrm{~d}$ ) and those stocked with naive PL (cultivation period under $60 \mathrm{~d}$ ). In addition, the theory would propose that the minimum incubation period for WSSV-PCR-negative PL Groups 1 to 5 was $4 \mathrm{~d}$, in contrast to $30 \mathrm{~d}$ for WSSV-PCR-positive Group 0, because the virus would be more virulent for naive PL. These speculations must await further experimental verification.

In conclusion, it can be seen that appropriate prevention programs can be implemented to control WSSV outbreaks in commercial shrimp ponds and that an important element in such programs should be the screening of PL for WSSV status before stocking. The proportion of successful harvests for WSSV-PCR-negative PL batches in the program described here was approximately $69 \%$. It is possible that this could be improved by increasing the sample size and the diag- 
nostic sensitivity of the PCR assay used. Ideally, only WSSV-free PL should be stocked in rearing ponds, but in times of shortage or unavailability of WSSV-PCRnegative $\mathrm{PL}$, it is possible that a presently unknown, low level of viral presence could be tolerated without a negative impact on crop success

Acknowledgements. The author thanks the owner of the farm studied for providing the information used and allowing it to be published for the benefit of the shrimp industry. He would also like to thank Dr Chris Baldock of Ausvet Animal Health Services, Queensland, Australia, and Daniel F. Fegan of BIOTEC, Thailand, for valuable suggestions in preparing the manuscript.

\section{LITERATURE CITED}

Adams A (1991) Response of penaeid shrimp to exposure to Vibrio species. Fish Shellfish Immunol 1:59-70

Chou HY, Huang CY, Wang CH, Chiang HC, Lo CF (1995) Pathogenecity of baculovirus infection causing white-spot syndrome in cultured penaeid shrimp in Taiwan. Dis Aquat Org 23:165-173

Flegel TW, Pasharawipas T (1998) Active viral accomodation: a new concept for crustacean response to viral pathogens. In: The 5th Asian Fisheries Forum, International Conference on Fisheries and Food Security Beyond the Year 2000. Chiengmai, Thailand, p 54

Flegel TW, Boonyaratpalin S, Withyachumnarnkul B (1997) Progress in research on yellow-head virus and white-spot virus in Thailand. In: Flegel TW, MacRae I (eds) Diseases in Asian Aquaculture III. Asian Fisheries Society, Manila, p 285-295

Kanchanaphum P, Wongteerasupaya C, Sitidilokratana N, Boonsaeng $V$, Panyim $S$, Tassanakajon A, Withyachumnarnkul B, Flegel TW (1998) Experimental transmission of white-spot syndrome virus (WSSV) from crabs to shrimp Penaeus monodon. Dis Aquat Org 34:1-7

Lan J, Pratanpipat P, Nash G, Wongwisansri S, Wongteerasupaya, Withyachumnarnkul B, Thammasart S, Lohawattanakul C (1996) Carrier and susceptible host of the systemic ectodermal and mesodermal baculovirus, the causative agent of white-spot disease in penaeid shrimp. In: World Aquaculture '96 Book of Abstracts, The 1996 Annual Meeting of the World Aquaculture Society, January 29-February 2 1996, Queen Sirikit National Convention Center, Bangkok, p 213-214

Lo CF, Leu JH, Ho CH, Chen CH, Peng SE, Chen YT, Chou CM, Yeh PY, Huang CJ, Chou HY, Wang $\mathrm{CH}$, Kou GH (1996a) Detection of baculovirus associated with whitespot syndrome (WSBV) in penaeid shrimps using polymerase chain reaction. Dis Aquat Org 25:133-141
Lo $\mathrm{CF}$, Ho CH, Peng SE, Chen CH, Hsu HC, Chiu YL, Chang $\mathrm{CH}$, Liu KF, Su MS, Wang CH, Kou GH (1996b) Whitespot syndrome (WSBV) detected in cultured and captured shrimp, crabs and other arthropods. Dis Aquat Org 27: $215-225$

Lo CF, Chang YS, Cheng CT, Kou GH (1998) Manitoring cultured shrimp for white spot syndrome virus (WSSV) infection during their growth period by polymerase chain reaction. In: The 5th Asian Fisheries Forum, International Conference on Fisheries and Food Security Beyond the Year 2000. Chiengmai, Thailand, p 127

Pratanpipat P, Nithimethachoke C, Akarajamorn A, Nash G, Withyachumnarnkul B, Thammasart $S$, Lohawattanakul C (1996) The efficacy of formalin for disinfection of systemic ectodermal and mesodermal baculovirus. In: World Aquaculture '96 Book of Abstracts, The 1996 Annual Meeting of the World Aquaculture Society, January 29-February 2 , 1996, Queen Sirikit National Convention Center, Bangkok, p 318

Rosenberry R (1995) Annual Report, Dec. 1995. Shrimp News International, San Diego, CA, p 26-28

Söderhäll K, Cerenius L (1992) Crustacean immunity. Annu Rev Fish Dis 2:3-23

Sung HH, Song YL, Kou GH (1991) Potential use of bacterin to prevent shrimp vibriosis. Fish Shellfish Immunol 1 $311-312$

Supamataya K, Hoffmann RW, Boonyaratpalin S, Kanchanaphum P (1998) Experimental transmission of white-spot syndrome virus (WSSV) from black tiger shrimp Penaeus monodon to the sand crab Portunus pelagicus, mud crab Scylla serrata and krill Acetes sp. Dis Aquat Org 32(2): $79-86$

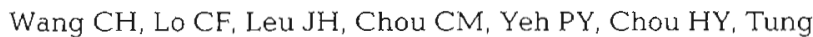
MC, Chang CF, Su MS, Kou GH (1995) Purification and genomic analysis of baculovirus associated with whitespot syndrome (WSS) of Penaeus monodon. Dis Aquat Org 23:239-242

Wongteerasupaya C, Vickers JE, Sriuraiwatana S, Nash G, Akarajamorn $A$, Boonsaeng $V$, Panyim S, Tassanakajorn A, Withyachumnarnkul B, Flegel TW (1995) A nonoccluded, systemic baculovirus that occurs in cells of ectodermal and mesodermal origin and causes high mortality in Penaeus monodon. Dis Aquat Org 21:69-77

Wongteerasupaya $C$, Wongwisansri $S$, Boonsaeng V, Panyim S, Pratanpipat P, Nash GL, Withyachumnarnkul B, Flegel TW (1996) DNA fragment of Penaeus monodon baculovirus PmNOBII gives positive in situ hybridization with white-spot viral infections in 6 penaeid shrimp species. Aquaculture 143:23-32

Wongwisansri S (1996) PCR-based method and in situ hybridization method for detection of white-spot virus in penaeid shrimp. Master's thesis, Department of Biochemistry, Faculty of Science, Mahidol University

Submitted: June 10, 1998; Accepted: September 4, 1999 Proofs received from author(s): November 26, 1999 